\title{
LIGHTWEIGHT AND MULTI-PURPOSE PARTITION FOR VERTICAL HOUSING
}

\author{
Eunike Kristi Julistiono ${ }^{1,2 *}$, Lilianny Sigit Arifin ${ }^{1}$, Bisatya Widadya Maer $^{1}$ \\ ${ }^{1}$ Department of Architecture, Petra Christian University, Siwalankerto 121-131, Surabaya, 60236, INDONESIA \\ ${ }^{2}$ School of Built Environment, University of New South Wales, Sydney, NSW 2052, AUSTRALIA \\ *Corresponding author; Email: kristi@petra.ac.id
}

\begin{abstract}
Vertical housings have been developed to solve housing quality degradation due to rapid urbanization. These housings are often lack of privacy and comfort, since the lay-out mostly consists of one open plan space with limited area. This paper presents a lightweight and multi-purpose partition to improve the living quality in vertical housings. The lightweight characteristic is intended to minimize structural loads, while the multi-purpose property allows the partition to be transformed into some furniture for spatial efficiency. A literature review and material surveys were performed prior to material selection and the design process. Then, physical model experiments were carried out to simulate the installation process and the transformation process of the partition modules into some furniture. Result show that the partition's weight is only $11-36.7 \%$ of the common partition wall, and when installed, the transformable property enables an adaptable space which can be adjusted to the occupants' different conditions.
\end{abstract}

Keywords: Adaptable space; do it yourself; lightweight material; modular construction; transformable partition.

\section{INTRODUCTION}

Rapid urbanization and concentration of economic activities in big cities have caused degradation of housing quality. As an essential need, dwelling is important to house human activities, as protection from natural environment and climate, and to selfactualize and gain respect from others (Julistiono, 2011). However, rapid development of public and commercial buildings has caused not only the scarcity of land for housings, but also a significant increase of land and house prices. Meanwhile, globalization and urbanization has encouraged more and more people to work and live in the city with the hope to improve their economy and living quality. Currently, $56 \%$ of the world's population lives in urban area, but this percentage will rise to $60 \%$ and $80 \%$ in 2030 and 3050 respectively (Al-Khodmany, 2018). Thus, for most middle and low-income people, housing has become a major problem. Some stay in low-quality houses, or even informal houses in slum area, causes unhealthy environments with poor quality and unsustainable houses among the city's neighbourhoods. While the rest live in sub-urban area, since it is more affordable, with the consequence of having to commute to the city centre every day and being burdened with transportation cost.

To ensure a healthy living environment in big cities, there has been massive development of vertical housings. Vertical housings in many scales have become solution for housing problems in big cities. In Hong Kong for example, the land scarcity is so crucial that mid and low-income flats with very small area units can be seen everywhere. In India, the government has implemented an affordable houses program with low-cost modular housing units to solve the increasing number of homeless people (Husain \& Shariq, 2018). In Indonesia, one million houses program has become one important focus of infrastructure development since 2015, as stated by President Joko Widodo.

Over the last 5 years, Indonesian Government has developed hundreds of low-income vertical housings (called 'rumah susun') in big cities in Indonesia. Ministry of Public Work and Public Housing has targeted the development of 550,000 housing units between 2014 and 2019. Up to 2017, 31,488 housing units has been fulfilled through development of 456 vertical housings. This number is estimated to increase into 52,000 housing units in 2019 (Simorangkir, 2018), which means that the target is still far away to be achieved. Most developments are in Java Island, with 30\% developments in Jakarta. Aside from maintaining existing vertical housings, the Provincial Government of Jakarta has planned to build 7 new vertical housings and revitalize 3 existing vertical housings in 2019 to facilitate 6,043 housing units for low-income communities (Tambun, 2019). Similarly, Surabaya Government has developed 18 vertical housings since 2016 for low-income communities (Putra, 2016).

To minimize the house price, most vertical housing units have very limited area and hence they lack comfort. In Indonesia, there are various types of 
vertical housings; 'rusunami' (low-income housing units that belong to the occupants), 'rusunawa' (lowincome housing units which are rented by the occupants), and subsidized apartments. Although having different names, these housing units have similar characteristics, they have very limited area to minimize the unit price. The government's standard sizes for low-income units are ranging from $18 \mathrm{~m}^{2}$ to $36 \mathrm{~m}^{2}$, whereas for middle-income apartments, the units' area is ranging from $45 \mathrm{~m}^{2}$ to $54 \mathrm{~m}^{2}$ (Adisurya, 2016). According to the standard of Department of Public Works, the minimum area required for each person is $7 \mathrm{~m}^{2}$. Hence, $18 \mathrm{~m}^{2}$ unit is sufficient for a family consisting of 2 people, but it is inadequate for a family of four. Reality shows that a large variety of the numbers of occupants has been founded in most lowincome vertical housings. Thus, the typical unit may not be adequate for some families. Besides having very limited area, these units usually comprise only one open plan space to accommodate various activities. For example, the lay-out of $18 \mathrm{~m}^{2}$ housing units frequently consists of an open plan space $(3 \mathrm{~m} \times 4.5 \mathrm{~m})$, a bathroom $(1.5 \mathrm{~m} \times 1.5 \mathrm{~m})$, and a balcony $(1.5 \mathrm{~m} \times$ $1.5 \mathrm{~m}$ ) (Figure 1). Hence, the $3 \mathrm{~m} \times 4.5 \mathrm{~m}$ space should be used for sleeping, eating, studying, and working all in that one space, and thus the space is lack of privacy and comfort. A separate bedroom is only possible if the unit area is more than $24 \mathrm{~m}^{2}$.

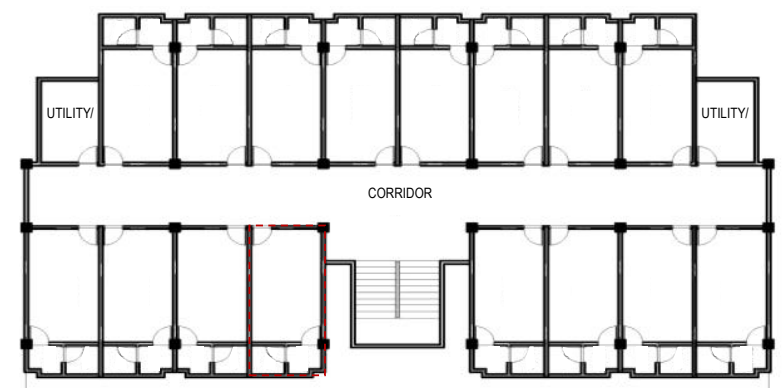

Figure 1. Typical lay-out for vertical housing with $18 \mathrm{~m}^{2}$ housing units

Moreover, replacing landed houses with vertical housings may not be satisfactory for some lowincome families. Traditionally, people get used to live in landed houses. Implementing vertical housing concept will require a change of the living habit. With vertical housing, the land will become a social belonging. Some families will live far away from the land, and thus lose a chance to interact with natural environment (landed garden). Furthermore, since in a vertical housing, all units have a typical lay-out, these units may not be suitable for different conditions of the occupants. Some families may consist of a couple, but others may consist of four members, some may have young-aged children, while others may have teenagers.

Considering that the aim of building vertical housings is to improve the living quality of middle and low-income community, it is important to design the vertical housings to ensure better living quality for the occupants. The limited area of the units as well as the typical open plan layout applied may produce new problems. Therefore, to ensure a satisfactory living quality, ideally a vertical housing unit (even with a typical lay-out) can be customized to accommodate different conditions of the occupants. Moreover, it should be able to ensure the occupants' privacy, health, and comfort.

Additionally, a sustainable house should be design with the capability to respond to the changing needs of its occupants. This means that the house layout can be adapted to the developing needs of its occupants. Throughout years, the condition of the occupants may change. A couple can have a child, or children, the children will grow and thus an extra room may be needed. Oppositely, a grown-up son/ daughter may get married and decides to live separately. A sustainable house should have certain adaptability and flexibility to prolong the building lifespan (Julistiono, 2011).

The objective of the research presented in this paper is to design a lightweight and multi-purpose partition to improve the living quality in vertical housings. The lightweight property is intended to minimize the structural loads, since originally most housing units are designed with open plan lay-out without considering additional structural loads of partition walls. Furthermore, a lightweight partition enables customized lay-out since it is easy to be constructed or dismantled by the occupants themselves and hence supports 'do it yourself' technology. Meanwhile, multi-purpose characteristic means that the partition can be transformed into some furniture to increase space efficiency in a limited area of each housing unit. Therefore, by proposing a lightweight and multi-purpose partition, it is expected that an adaptable space in each vertical housing unit can be achieved, and thus although with typical and limited area, these units can function efficiently and satisfy the occupants' needs.

\section{RESEARCH METHODOLOGY}

The research was started by setting the research background, research problem and objective, as well as the research methodology. The research problem is to design a lightweight partition which can be transformed into some furniture to accommodate various 
activities in limited area of vertical housing units. The objective is to improve the living quality in limited area of typical vertical housing units, as well as to allow customized lay-out of the units to accommodate distinct conditions of the occupants.

Before the design process, criteria of the designed partition was defined:

- The sheet material is used to allow the partition to behave as a modular construction.

- The partition module produced should be lightweight enough, so that it can be assembled by the occupants themselves, without additional support from professionals.

- The material used is neat in appearance and thus the partition is aesthetic enough to be used without finishing process.

- Although lightweight, each partition module should be sturdy enough, to be function as furniture as well as interior partition.

- The partition modules can be assembled into a partition with a dimension of $3 \mathrm{~m}$ wide by $3 \mathrm{~m}$ high, to suit an $18 \mathrm{~m}^{2}$ vertical housing unit (low-income units' smallest area).

After the criteria set, the research was begun with literature review and site surveys, to obtain information regarding similar research found and to find possible materials used. From site surveys, alternative materials were chosen, and then the best possible material was decided. Then, design process was performed to design the partition modules, as well as the best possible construction to assemble the modules with 'do it yourself' technology.

Once the material has been chosen, the design drawing was created. Then, the physical models were produced to model each designed module and the assembling process. Two phases of modelling were included in the research; physical model with 1:10 scale and real physical model with 1:1 scale. The 1:10 model is intended to examine the transformation process of each module into the furniture, as well as the assembling process of the modules into a partition. While the 1:1 model is required to test the design resulted in terms of its strength, functional practicality, and lightweight characteristic.

\section{LIGHTWEIGHT WALL MATERIALS AND TRANSFORMABLE FURNITURE}

Recently, modular construction and lightweight partition have been developed as solutions for economical and sustainable housings. By utilizing modern prefabrication methods, modular construction can be built in a very limited time, and thus it is work and cost efficient with superior quality (Ferdous et al., 2019; Generalova et al., 2016; Jin et al., 2018). Furthermore, a modular construction enables an adaptability in the house lay-out through the implementation of a knock down and/or incremental construction. In here, a lightweight partition is beneficial to minimize the structural loads and to produce an easy to assembled/dismantled construction. Installing a lightweight partition in a vertical housing unit will allow the occupants themselves to participate in the construction process or in the space adaptation process when it is needed.

\section{Lightweight Wall Materials}

Following the trend of modular prefabricated houses as a low-cost housing solution, recent research has focused on improving the performance of existing partition walls in term of their weight or finding alternative lightweight materials.

\section{Lightweight concrete}

Lightweight concrete has become popular and replaced the use of concrete and bricks for house construction. The benefits include reducing structural loads, improving thermal performance and durability (Bremner, 2008). Lightweight concrete panels and blocks in various brands (Table 1) have been used widely to produce a lightweight construction.

Research has been found on finding alternative materials for lightweight concrete wall, such as using straw waste to replace aggregate in concrete mix (Widayanto et al., 2011) and bamboo reinforced concrete wall (Himasree et al., 2017).

Table 1. Lightweight wall panels from various brands.

\begin{tabular}{lccc}
\hline & Hebel & Grand Elephant & Wallplus \\
\hline Density & $780 \mathrm{~kg} / \mathrm{m}^{3}$ & $650 \mathrm{~kg} / \mathrm{m}^{3}$ & $700 \mathrm{~kg} / \mathrm{m}^{3}$ \\
Wall panel thickness & $7.5-15 \mathrm{~cm}$ & $7.5-20 \mathrm{~cm}$ & $5-12 \mathrm{~cm}$ \\
Wall panel width & $60 \mathrm{~cm}$ & $60 \mathrm{~cm}$ & $61 \mathrm{~cm}$ \\
Wall panel length & $2.4-3.3 \mathrm{~m}$ & $4-6 \mathrm{~m}$ & $2.44 \mathrm{~m}$ \\
\hline
\end{tabular}

\section{Partition board}

Partition board have been widely used for indoor partition walls. The advantage is reducing structural loads since these sheet materials are lighter compared to lightweight concrete.

- Gypsum board, known as drywall or plasterboard, is made of gypsum wrapped in between two sheets of paper. It is widely used for interior partition and ceiling. The advantages are easy installation, fire resistance, sound isolation, durability, economy, and lightweight. It is available in $9 \mathrm{~mm}, 12 \mathrm{~mm}$, and $15 \mathrm{~mm}$ thicknesses. 
- Kalsi board is made of a mixture of silica sand, cement, and cellulose fibre. It has a strength as cement and flexibility as plywood. It is available in 3-20 mm thicknesses. The benefits are its strength but elastic characteristic (can be bended at certain degree) and durability, as well as non-toxic property and recyclability.

\section{Eco wall}

Following the rising awareness of sustainable design, many studies have focused on finding alternative wall materials which are environmental friendly, consume low energy and low resources to produce, or recycled materials. An example of eco wall is POLLIBrick, which is an innovative material, made of recycled Polyethylene Terephthalate Polymer, founded by Miniwiz. From mere recycled bottles, Miniwiz created a 3D honeycomb interlocking structure which is translucent, naturally insulated, and durable (Figure 2), used in nine storeys high EcoARK Pavilion (Wang, 2017).
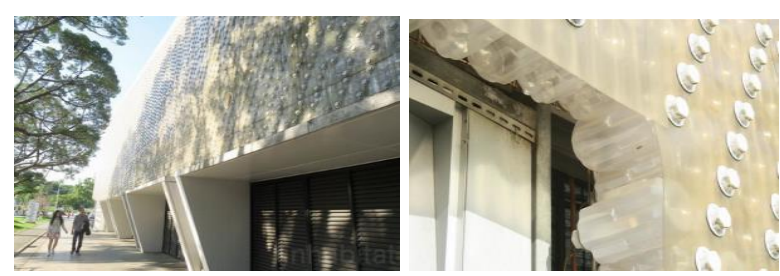

Figure 2. POLLI-Brick Wall at EcoARK Pavilion, Taiwan (Wang, 2017).

Since recent research has focussed on finding lightweight wall alternatives (Mateus et al., 2013; Novais et al., 2019), lightweight wall/partition in various sizes and materials have been widely offered by industries. However, most have no adaptability or multi-purpose property, and the installation required specific skills. In this research, it is intended that the designed partition has multi-purpose characteristic and can be installed by the occupants themselves.

\section{Transformable Furniture}

The limited area of indoor spaces has encouraged development of transformable furniture, which is a type of furniture that can be transformed into different functions. The objective is to accommodate distinct activities with multi-purpose and space-saving furniture. For example is a sofa and shelf (Hays \& Mason, 2018) or a working desk (Rogers, 2016) which can be transformed into a comfortable bed as a great solution for a space that functions as a living room/study room as well as a bedroom (Figure 3).

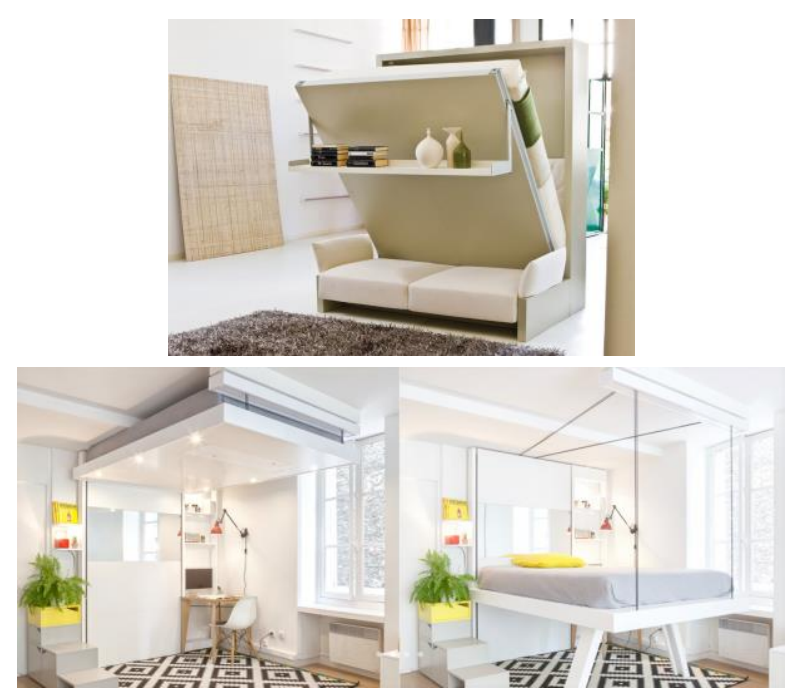

Figure 3. Examples of transformable furniture (Hays and Mason, 2018; Rogers, 2016).

The benefit of transformable furniture in saving the space has given inspiration to implement the transformable partition concept in the design process, so that the designed partition is not only lightweight, but also multi-functional.

\section{DESIGN PROCESS}

\section{Material Survey}

The design process was preceded by surveys to various building material suppliers to find possible lightweight sheet material to be used. Below are some possible materials considered.

\section{Bamboo laminated board}

It is made of layers of bamboo strips, glued and pressed together, to produce a thin sheet material with approximately $1 \mathrm{~cm}$ thickness. Bamboo laminated (Figure 4a) is commonly available in the form of short board, with $25-33 \mathrm{~cm}$ wide and $55 \mathrm{~cm}$ long. The weight of one sheet board is $2.3 \mathrm{~kg}$. Although natural bamboo is still more popular and widely used as building materials, for exterior and interior components respectively, the use of bamboo laminated has increased, for furniture products as well as floor, wall, and finishing materials.

\section{Air-conditioner insulation sheet}

During the site survey, this material is founded as an alternative due to its lightweight but sturdy characteristics. It is an AC insulation or AC ducting material, comprises aluminium sheet and foam materials (Figure 4b). This material is an excellent insulation, it 
is very lightweight and durable. The dimension of each sheet is $2 \mathrm{~cm}$ in thickness, $120 \mathrm{~cm}$ wide, and $4 \mathrm{~m}$ long. The weight is approximately $1.48 \mathrm{~kg} / \mathrm{m}^{2}$.

\section{PVC sheet}

It is widely used for doors, windows, and furniture. The benefit of this Poly Vinyl Chloride (PVC) sheet is its lightweight and easy to handle properties (Figure 4c). It is strong, waterproof, and resistant towards termite, corrosion, and fire. It is available in dimension of $1.22 \mathrm{~m} \times 2.44 \mathrm{~m}$ and $3-20$ $\mathrm{mm}$ thickness range. The weight of each $2 \mathrm{~cm}$ sheet is $1.4 \mathrm{~kg}$.
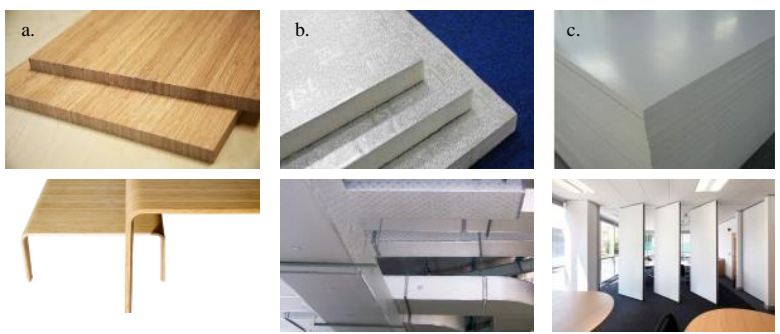

Figure 4. Bamboo laminated board (a), AC insulation sheet (b), and PVC board (c), and their example applications.

\section{Design and Drawings}

From three above materials which were surveyed and observed, PVC sheet was chosen, due to its lightweight character, neat and aesthetic appearance (even without finishing), as well as the material availability and its practicability as partition and furniture materials.

Considering the common dimension of low-cost housing units, a $1 \mathrm{~m} \times 1 \mathrm{~m}$ module was chosen for each designed partition module, so that the modules can be assembled into $3 \mathrm{~m}$ high partition wall with various width according to the width of the housing unit. In the design process, the partition is assumed to be $3 \mathrm{~m}$ wide and $3 \mathrm{~m}$ high, consisting of 9 partition modules. To achieve a multi-purpose function, 4 modules were designed, including a plain partition module and 3 transformable modules (Figure 5) for 3 distinct activities in the house:

- Transformable module 1 is a partition module which can be transformed into a desk, to accommodate studying or working activities for the children or parents.

- Transformable module 2 is a module that can be converted into a shelf, hence it is useful to keep some books, toys, drinks or food.

- Transformable module 3 is a module which can be transformed into a cupboard to store clothes or other belongings.
With the 4 designed modules, various arrangements of partition can be produced. Figure 6 shows an example of $3 \mathrm{~m} \times 3 \mathrm{~m}$ customized partition produced by 4 designed modules.

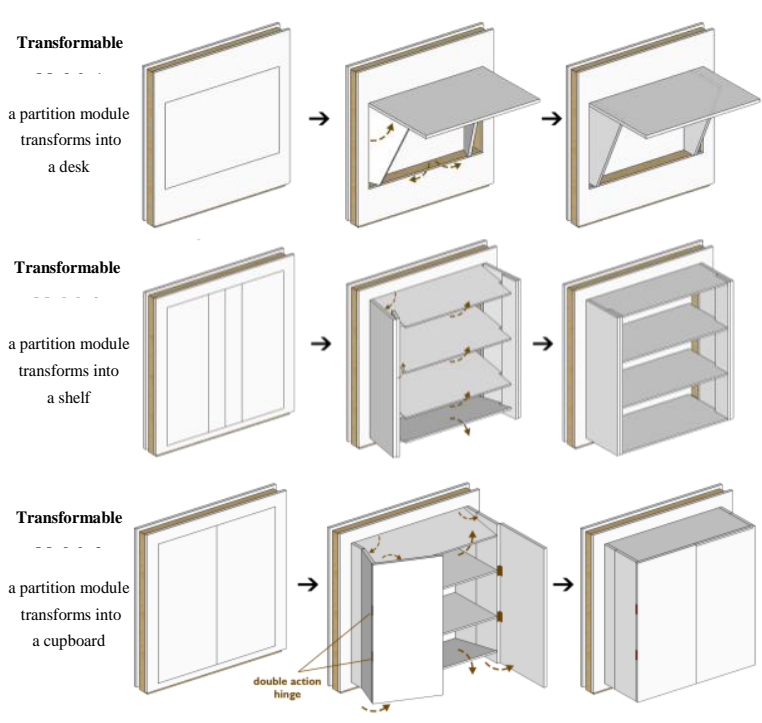

Figure 5. Three designed transformable partition modules.

Considering that PVC sheet cannot be screwed, the sheet was layered with sheets of multiplex. For the plain module, the laminated sheets of multiplex and PVC sheet were attached to both sides of the square wood frame to produce the module. The tongue and groove joints were designed and implemented in the construction, to allow the modules to be assembled such as a jigsaw puzzle. To install the partition, first the base beam and the timber post should be located in the proper position. Then, 3 modules can be assembled from the bottom into the top with tongue and groove joints. After that, another timber post is attached to secure the construction, and then 3 other modules can be assembled, following with another timber post attachment. Joints between the modules are shown in Detail A, B, and C (Figure 7). A specific hinge, called double-action hinge was designed for the transformable module 3 , in which the cupboard doors should be able to be opened or closed neatly (Figure $7 d)$.
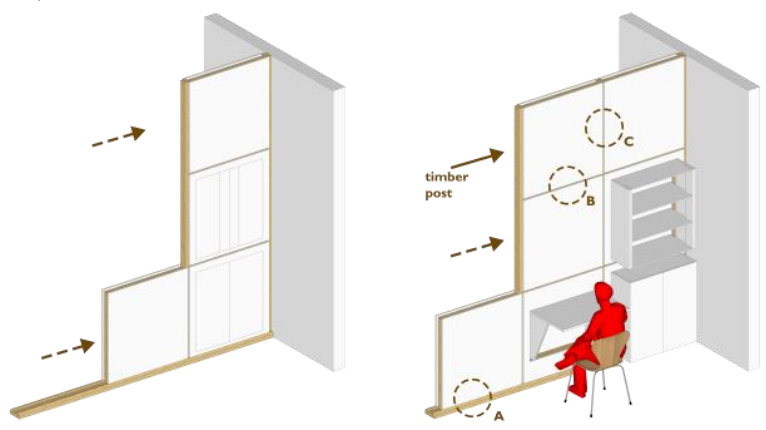

Figure 6. Customized $3 \mathrm{~m} \times 3 \mathrm{~m}$ partition produced with 4 designed modules 


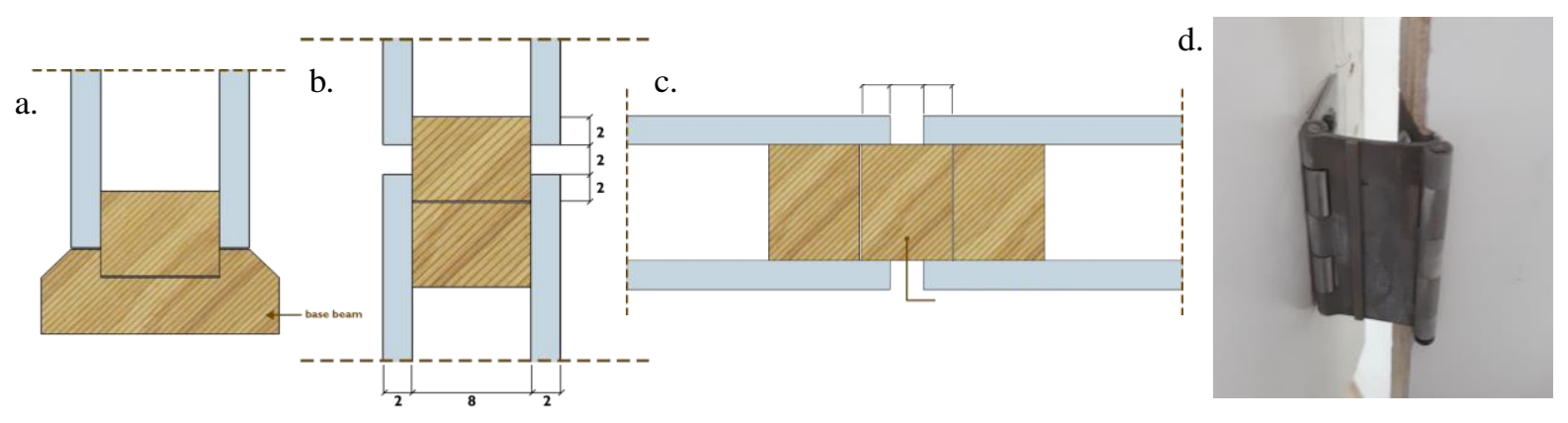

Figure 7. Detail A (a), B (b), C (c) show the joints between modules, and the double action hinge for transformable module $3(d)$.

\section{Physical Model Experiments}

After design and drawings were completed, the physical model experiments were performed.

\section{1:10 Physical model}

This was produced to actualize the 4 designed modules, as well as to simulate the assembling process of the 9 modules into a complete $3 \mathrm{~m} \times 3 \mathrm{~m}$ partition wall (Figure 8).
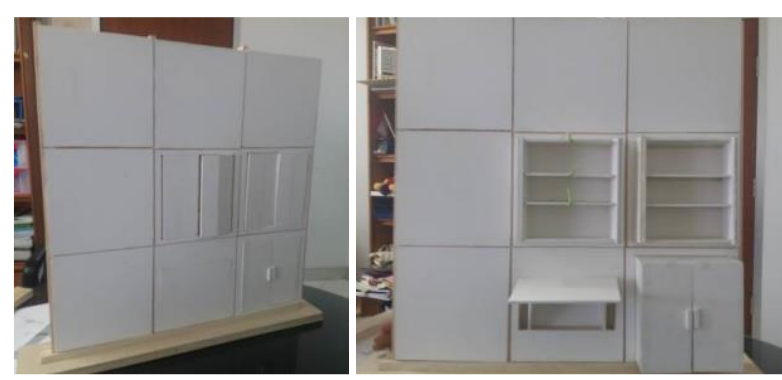

Figure 8 1:10 scale Physical Model in flat partition (left) and multi-purpose (right) modes.

\section{1:1 Physical model}

A physical model with a scale of 1:1 was created to examine the actual construction of the modules (Figure 9). Due to limited research budget, the model was constructed with $2 \mathrm{~m} \times 3 \mathrm{~m}$ wall dimension, consisting of 3 plain modules, and 3 transformable modules. This model is useful to simulate the real transformation process from a flat partition mode into a multi-purpose mode (when each module functions as furniture), to observe the practicality of the conversion process, as well as the construction details and the weight of the designed modules.

\section{RESULTS AND DISCUSSION}

After 1:1 scale physical model was completed, the 4 modules were weighed, to examine the lightweight characteristic of the designed partition. Result shows that the plain module's weight is $27.5 \mathrm{~kg}$, while the weight of each transformable module is approximately $38 \mathrm{~kg}$. To examine the lightness of the partition, the weight of the modules was compared with the weight of the partition walls constructed with several common materials. In here, the plain module was the one to be compared since the common partition wall can not be converted into furniture such as the 3 designed transformable modules.
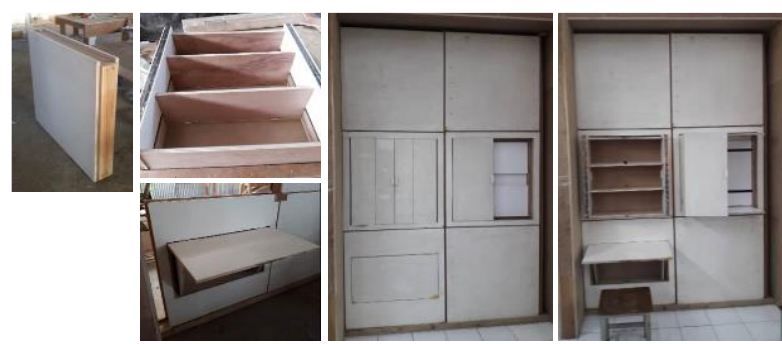

Figure 9. 1:1 scale Physical Model.

Table 2. Weight comparison of different wall materials.

\begin{tabular}{lcccc}
\hline $\begin{array}{c}\text { Type of } \\
\text { materials }\end{array}$ & $\begin{array}{c}\text { Designed } \\
\text { plain module } \\
\text { (10cm thick) }\end{array}$ & $\begin{array}{c}\text { Brick } \\
\text { wall } \\
\text { (15cm } \\
\text { thick) }\end{array}$ & $\begin{array}{c}\text { Hebel } \\
\text { lightweight } \\
\text { concrete } \\
\text { panel }(\mathbf{1 0 c m} \\
\text { thick) }\end{array}$ & $\begin{array}{c}\text { Grand } \\
\text { Elephant } \\
\text { panel } \\
\text { (10cm thick) }\end{array}$ \\
\hline $\begin{array}{l}\text { Weight of } \\
\begin{array}{l}1 \mathrm{~m} \times 1 \mathrm{~m} \\
\text { module/wall }\end{array}\end{array}$ & $27.5 \mathrm{~kg}$ & $250 \mathrm{~kg}$ & $108 \mathrm{~kg}$ & $75 \mathrm{~kg}$ \\
\hline
\end{tabular}

Table 2 shows that the plain PVC module is very lightweight, compared to the wall partition with the same dimension, constructed using common wall materials. The weight of the plain module is $27.5 \mathrm{~kg}$, which is only $11 \%$ of the brick wall, $25.4 \%$ of Hebel lightweight concrete panel, and $36.7 \%$ of the Grand Elephant panel.

The transformation process of each transformable module has been simulated through 1:1 scale physical model to ensure its practicality. The tongue and groove joints between modules allow the 4 modules to be assembled into a wall partition with various configuration, according to the house occupants' distinct conditions, producing a customized, multi-purpose, and adjustable partition. 


\section{CONCLUSION}

From this research, it can be concluded that using PVC partition to replace the common wall partition is very beneficial in reducing the construction weight.

- The plain module is proven to be very lightweight, as shown at Table 2, that for each $1 \mathrm{~m} \times 1 \mathrm{~m}$ plain module, the weight is only $11-36.7 \%$ of the common wall partition.

- The average weight of 3 designed transformable modules is $38 \mathrm{~kg}$, which is only $15-50 \%$ of the common wall partition.

This lightweight characteristic will ensure the possibility of the designed partition to be constructed and dismantled by the occupants themselves with 'do it your self' concept.

The multi purpose characteristic of the transformable modules is beneficial in increasing the space efficiency in very limited space. Hence, through the installation of this designed partition, a customized lay-out can be achieved even with a typical vertical housing unit. Consequently, it will not only humanise the vertical housing to function more comfortably, but also give a chance for the occupants to organize their own unique interior spaces.

It is realized that to improve the quality and functionality of the assembled partition, this research needs to be continued further in the future. Several areas to explore further include finding alternative frame material for the partition modules to minimize the weight further, observing the panel durability over time and the practicality of conversion process to test and evaluate the multi-purpose characteristic of the modules, and testing the accoustic quality of the partition produced.

\section{REFERENCES}

Adisurya, S.I. 2016. Kajian besaran ruang pada unit rumah susun di Jakarta. [Study of area adequacy at vertical housing units in Jakarta]. Dimensi 1(1): 93-112 [in Bahasa Indonesia]. https://www. trijurnal.lemlit.trisakti.ac.id/dimensi/article/view/ $1781 / 1541$

Al-Kodmany, K. 2018. The sustainability of tall building developments: A conceptual framework. Buildings, 8(7). DOI:10.3390/buildings8010007.

Bremner, T.W. 2008. Lightweight concrete. In Mindess, S. (ed.). Developments in the formulation and reinforcement of concrete. Woodhead Publishing, Cambridge. DOI: 10.1533/97818456 94685.167
Ferdous, W., Bai, Y., Ngo, T.D., Manalo, A. \& Mendis, P. 2019. New advancements, challenges and opportunities of multi-storey modular buildings A state-of-the-art review. Engineering Structures, 183, 883-893. DOI:10.1016/j.engstruct.2019.01. 061.

Generalova, E.M., Generalov, V.P. \& Kuznetsova, A.A. 2016. Modular buildings in modern construction. Procedia Engineering 153: 167-172. DOI: 10.1016/j.proeng.2016.08.098

Hays, J. \& Mason, B. 2018. 8 transforming furniture solutions for small space living. The Spruce, 17 September. Accessed July 2019 from https://www. thespruce.com/transforming-furniture-for-smallspaces-4058276

Himasree, P.R., Ganesan, N. \& Indira, P.V. 2017. Bamboo as a substitute for steel in reinforced concrete wall panels. IOP Conference Series: Earth and Environmental Science, 80 (012041): 1-8. DOI:10.1088/1755-1315/80/1/012041

Husain, S.F. \& Shariq, M. 2018. Low cost modular housing - A review. International Conference on Advances in Construction Materials and Structures. IIT Roorkee, Roorkee, India. https://www. researchgate.net/publication/323099699_Low_C ost_Modular_Housing-A_Review

Jin, R., Gao, S., Cheshmehzangi, A. \& AboagyeNimo, E. 2018. A holistic review of off-site construction literature published between 2008 and 2018. Journal of Cleaner Production, 202, 1202-1219. DOI:10.1016/j.jclepro.2018.08.195.

Julistiono, E.K. 2011. Sustainable incremental house with modular construction. Proceedings of International Conference "Local Wisdom in Global Era". Duta Wacana Christian University, Yogyakarta, Indonesia. http://fportfolio.petra.ac.id/ user_files/04-001/Paper\%20CIB\%20Eunike.pdf

Mateus, R., Neiva, S., Braganca, L., Mendonca, P. \& Macieira, M. 2013. Sustainability assessment of an innovative lightweight building technology for partition wall - Comparison with conventional technologies. Building and Environment 67: 147-159. DOI:10.1016/j.buildenv.2013.05.012

Novais, R.M., Senff, L., Carvalheiras, J., Seabra, M.P., Pullar, R.C., \& Labrincha J.A. 2019. Sustainable and efficient cork - inorganic polymer composites: An innovative and ecofriendly approach to produce ultra-lightweight and low thermal conductivity materials. Cement and Concrete Composites 97: 107-117. DOI: 10.1016/ j.cemconcomp.2018.12.024.

Putra, Y.M.P. 2016. Pemkot Surabaya tambah 18 titik rusun [Surabaya Government adds 18 new vertical housings]. Republika, 6 April [in Bahasa 
Indonesia]. Accessed May 2019 from https://www. republika.co.id/berita/nasional/daerah/16/04/06/o 57 sxg284-pemkot-surabaya-tambah-18-titik-rusun Rogers, S.A. 2016. Small space shape shifters: 13 Transforming furniture designs. Web Urbanist, 25 May. Accessed July 2019 from https://weburbanist.com/2016/05/25/small-space-shape-shifters-13-transforming-furniture-designs/

Simorangkir, E. 2018. Pemerintah cuma bisa bangun 52.000 rusun hingga 2019. [Government can only build 52,000 vertical housing units up to 2019]. Detikfinance, 13 September [in Bahasa Indonesia]. Accessed May 2019 from https://fi nance.detik.com/properti/d-4210558/pemerintahcuma-bisa-bangun-52000-rusun-hingga-2019.

Tambun, L.T. 2019. Tahun ini, DKI bangun tujuh rusun baru senilai $\mathrm{Rp} 709 \mathrm{M}$. [This year, Jakarta will build 7 new vertical housings worth 709 billions]. Berita Satu, 18 January [in Bahasa Indonesia]. Accessed May 2019 from https://www. beritasatu. com/megapolitan/ 533300/tahun-inidki-bangun-tujuh-rusun-baru-senilai-rp-709-m.

Wang, L. 2017. Amazing building made from 1.5 million plastic bottles withstands fires and earthquakes. Inhabitat, 15 May. Accessed May 2019 from https://inhabitat.com/amazing-plasticbottle-architecture-withstands-earthquakes-intaipei/

Widayanto, E., Krisnamurti \& Aswatama, K. 2011. Pengembangan model dinding pracetak dari limbah jerami sebagai pengganti bata pada rumah di wilayah rawan gempa. [Development of precast wall model made from straw waste, as replacement of bricks, for houses at earthquake prone area]. Rekayasa 8(1): 13-24 [in Bahasa Indonesia]. https://www.researchgate.net/publication/316547879_PENGEMBANGAN_MOD EL_DINDING_PRACETAK_DARI_LIMBAH _JERAMI_SEBAGAI_PENGGANTI_BATA_ PADA_RUMAH_DI_WILAYAH_RAWAN_ GEMPA 